Primljen / Received: 25.4.2012.

Ispravljen / Corrected: 7.2.2013.

Prihvaćen / Accepted: 21.2.2013.

Dostupno online / Available online: 10.4.2013.

\section{Classification of building elements as a function of air permeability measurements}

Authors:

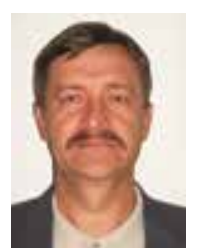

Prof. Željko Koški, PhD.

University J.J. Strossmayer of Osijek

Faculty of Civil Engineering

zkoski@gfos.hr

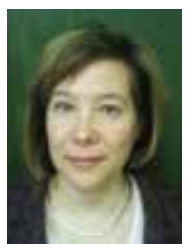

Asst. Prof. Irena Ištoka Otković, PhD. CE University J.J. Strossmayer of Osijek Faculty of Civil Engineering iirena@gfos.hr

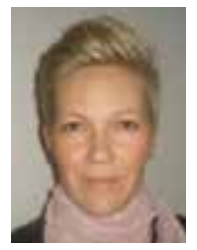

Ivana Miličević, BSc. CE

University J.J. Strossmayer of Osijek

Faculty of Civil Engineering

ivana.milicevic@gfos.hr

\section{Željko Koški, Irena Ištoka Otković, Ivana Miličević}

Subject review

\section{Classification of building elements as a function of air permeability measurements}

Starting from the need to increase energy efficiency of buildings, the thermal quality of selected envelope elements of existing residential buildings is chronologically analyzed in the paper. Following this analysis, the most significant parameters for classification of boundary building elements are selected, in order to establish criteria for selection of a representative sample of the existing housing stock. The hypothesis of a dependence between the input factors selected and the airtightness is proposed, and the "Blower door" and "Tracer gas" methods for airtightness measurement are presented.

Key words:

residential buildings, airtightness, energy saving, energy efficiency

Pregledni rad

Željko Koški, Irena Ištoka Otković, Ivana Miličević

\section{Klasifikacija elemenata zgrada u funkciji mjerenja zrakopropusnosti}

Polazeći od potrebe poboljšanja energetske učinkovitosti u zgradama, u članku se kronološki analizira toplinska kvaliteta odabranih elemenata omotača postojećih stambenih zgrada. Temeljem analize odabrani su najznačajniji parametri za klasifikaciju obodnih građevinskih elemenata s ciljem stvaranja kriterija za odabir reperezentativnog uzorka postojećeg stambenog fonda. Postavljena je hipoteza odredene zavisnosti odabranih ulaznih faktora i zrakopropusnosti koja se planira dokazati terenskim mjerenjima u nastavku istraživanja. Ukratko se predstavljaju "Blower door" i "Tracer gas" metode mjerenja zrakopropusnosti.

Ključne riječi:

stambene zgrade, zrakopropusnost, ušteda energije, energetska učinkovitost

Übersichtsarbeit

Željko Koški, Irena Ištoka Otković, Ivana Miličević

\section{Klassifizierung von Gebäudeelementen in Bezug auf Luftdurchlässigkeitsmessungen}

Ausgehend von der Notwendigkeit die Energieeffizienz in Gebäuden zu verbessern, wird in dieser Arbeit die thermische Qualität ausgewählter Gebäudehüllenelemente für bestehende Wohngebäude chronologisch analysiert. Auf den gegebenen Analysen beruhend, sind die bedeutendsten Parameter für die Klassifizierung von äußeren Bauelementen ausgewählt, um Kriterien für die Auswahl repräsentativer Proben des existenten Wohngebäudebestands zu definieren. Die Hypothese einer bestimmten Abhängigkeit ausgewählter Eingangsparameter und der dazugehörigen Luftdurchlässigkeit wird aufgestellt. Außerdem werden zwei Methoden zur Messung der Luftdurchlässigkeit ("Blower door" und "Tracer gas") beschrieben.

Schlüsselwörter

Wohngebäude, Luftdurchlässigkeit, Energiesparen, Energieeffizienz 


\section{Introduction}

The immediate future of our civilization depends mostly on ensuring sufficient quantities of cheap energy and protection the human environment. Ensuring sufficient amount of energy is based, inter alia, on the development of new technologies of utilization of renewable and other energy sources, as well as the rational use of available energy. We are faced with solving a very complex issue, which has to meet the growing global demand for energy, while reducing greenhouse gas emissions, which have very harmful impact to the environment.

There are examples of successful rationalization of the use of available energy in various fields of human activities. Everyone knows the example of automotive industry that managed to reduce fuel consumption of cars several times by great technological innovations in the last four decades with tendency of further large savings.

When one comes to energy consumption in buildings, the situation is somewhat different. Buildings are complex energy systems and the largest individual consumers of energy in Europe that spend more than $40 \%$ of total generation [1]. One part this energy is wasted because buildings built decades ago do not meet current standards and regulations in the field of thermal insulation and energy efficiency of buildings. This issue is harder also because the large percentage of such buildings will be operational for many years and spend (waste) large amounts of energy required for heating, cooling, equipment operation and lighting, if some measures are not taken.

As a new member of the European Union from 1 July 2013 the Republic of Croatia will accept and implement all the resolutions, declarations and directives with the aim of improving energy efficiency in building sector. Article 29 of EU Parliament Resolution No. 2007/2016, dated 31 January 2008 sets forth that since 2011 passive house or very low-energy building shall become the standard in building sector.

Achieving good energy efficiency in buildings cannot be attained without application of the same criteria and systematic renewal of existing buildings. Implementation of the principle of rational energy use in existing buildings directly contributes to the architectural and energy requirements of modern life in buildings. Achieving adequate energy efficiency in buildings indirectly contributes to biological and ecological requirements because pleasant residence contributes to human health, and lower energy consumption reduces $\mathrm{CO}_{2}$ emissions to the atmosphere, which contributes significantly to the environmental protection.

Controlled air ventilation is a very important element in achieving efficient energy balance of passive houses and lowenergy buildings. Low airtightness of the room envelopes in buildings is crucial to ensure adequate controlled ventilation. Ventilation is also important from the point of view of energy consumption and achieving adequate thermal comfort in buildings. Despite the importance of ventilation in buildings, there is not enough information available about the exchange of air and airtightness in existing or even in new buildings. This paper aims to create classification of existing residential buildings based on the thermal properties categorization of the most important envelope elements of buildings, materials for load-bearing structure, position of residential units in the building and construction period. Establishing a clear classification of external walls and windows of residential buildings would enable the determination of a representative sample to measure the airtightness.

Building classification will be determined on the basis of the most important characteristics of buildings, especially involving the construction period and energy performance of the building envelope. Thermal quality of windows plays particularly important role in the building classification because the ventilation heat losses through windows are very important element in the airtightness analysis of the building envelope. Window quality in buildings was significantly changed in the last about hundred years. Characteristics of traditional and old buildings in the region are very similar, but new buildings, built in the last few decades, have different characteristics.

By data processing on the measured airtightness values for different types of residential buildings from different periods of construction, necessary information will be obtained that will be used in the future processes of systematic reconstruction of buildings in order to achieve the appropriate energy efficiency in buildings, adequate thermal comfort and conformity with recommendations of the European Union in this area.

\section{Classification of selected envelope elements of residential buildings}

General quality of buildings has been changing through different periods of construction in our region, depending on the climate, economic, technical-technological and sociological influences. In addition, the price of energy required for heating and regulations in the field of thermal protection of buildings, which appeared for the first time in 1970. [2], and later systematically supplemented since 1980 had a particular impact on the quality [3].

Complete future reconstruction of existing buildings in order to achieve adequate energy efficiency should be based on the determination of properties of building elements. The airtightness of the building envelope is one of the main features of which energy consumption depends on. The term building envelope implies several types of opaque and transparent peripheral structures or elements that separate an internal heated (cooled) from unheated (uncooled) or external space. Each of these peripheral structures contributes to the overall heat quality proportionally to the share of a particular structure in the total surface area of the building envelope. Existing residential buildings vary considerably in thermal quality of the building envelope. Heat losses in the building depend in general on the heat loss coefficient due to transmission (U) and the coefficient of thermal loss caused by ventilation. 
In addition to the thermal envelope quality, its airtightness is influenced by construction technology, method of connecting different elements and the envelope breakthroughs for installations. Restrictions of the building envelope airtightness and building ventilation are specified by Technical regulations about thermal energy savings and thermal protection in buildings (OG 76/2007 - Articles 20-24).

\subsection{Thermal quality of opaque envelope parts of residential buildings}

Opaque components typically account for a larger part of the building envelope, which in existing residential buildings usually amounts to about $75-80 \%$ of its total surface area. The largest percentage of the building envelope surface area consists of external walls, which is logical, because they separate the internal from external space with four from six sides. The inherited housing stock in buildings in use has very different quality of the building envelope. Position of each of the elements that makes the building envelope is defined separately because it has different physical characteristics of heat flow, i.e. heat passage. This difference between building elements according to the building position is also important for the airtightness. There is an important difference in airtightness of elements that may be exposed to strong air currents (roof, external walls) and elements that are protected from air currents by their position in the building (floors on the ground, walls to the ground). According to position, theoretical envelope of a residential building comprises of nine different peripheral elements (Figure 1):

\section{LEGEND}

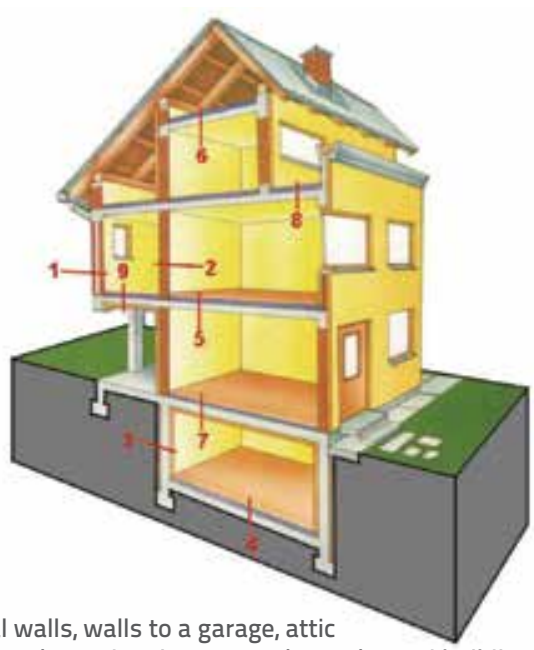

2. walls to unheated staircase or other unheated building rooms

3. walls to the ground

4. walls on the ground

5. ceilings between apartments or various heated functional units

6. ceilings to the attic

7. ceilings to unheated basement, other unheated space

8. flat and sloping roofs above heated spaces

9. ceilings above outside space and garages

Figure 1. Residential building envelope
Analysis of the most frequently built external walls in the continental part of Croatia, in different construction periods, can lead to the classification of thermal quality of opaque envelope parts of existing residential buildings. External stone walls of residential buildings in the coastal region of Republic Croatia are not the subject of analyses in this paper because of their traditional specific properties.

\subsubsection{Construction period before 1900}

This construction period is characterized by relatively thick structures of external walls as a result of the then level of technological development in construction of residential buildings. External walls in continental Croatia were almost entirely made of full bricks plastered on both sides. The external walls thickness were mostly 75 or $60 \mathrm{~cm}$ as a result of the use of old brick old size (format). The result of such construction was good thermal quality of walls because their thickness contributed to relatively good thermal transmittance coefficients " $U$ " which are at the border of meeting the maximum allowed values also under the present regulations. Figure 2 shows temperature curves of external walls in winter period with its thermal transmittance coefficient " $U$ " for structure of the two most frequently built external wall from that period.

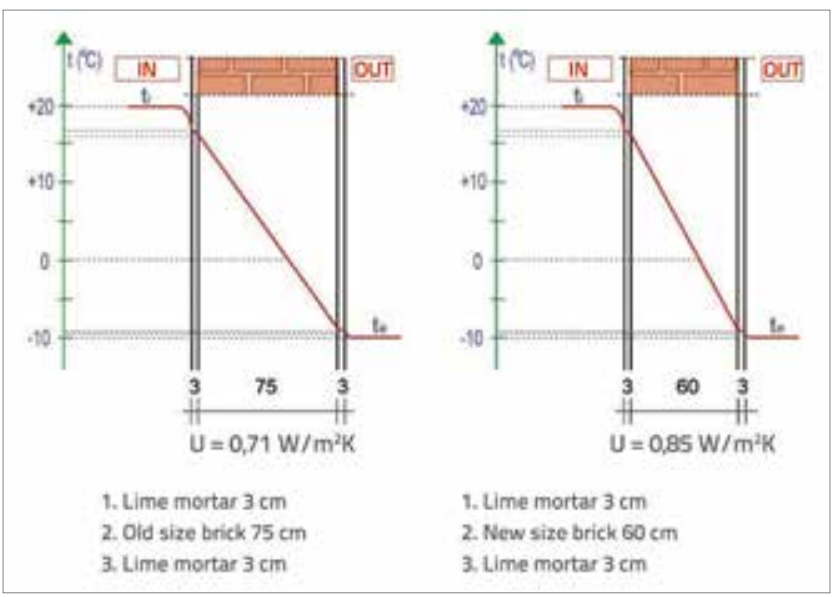

Figure 2. Typical external walls before 1900

\subsubsection{Construction period 1901-1945}

Technological advances in construction of buildings in this period lead to construction of thinner external brick wall, which resulted in lower quality in thermal terms. Towards the end of the period new brick size was introduced $(25 \times 12 \times 6.5$ $\mathrm{cm})$, which also lead to construction of thinner external brick walls (Figure 3.).

Usual construction of external wall with thickness of one and a half brick fell from 45 to $38 \mathrm{~cm}$ thickness after the introduction of the new brick size around the 1930. 


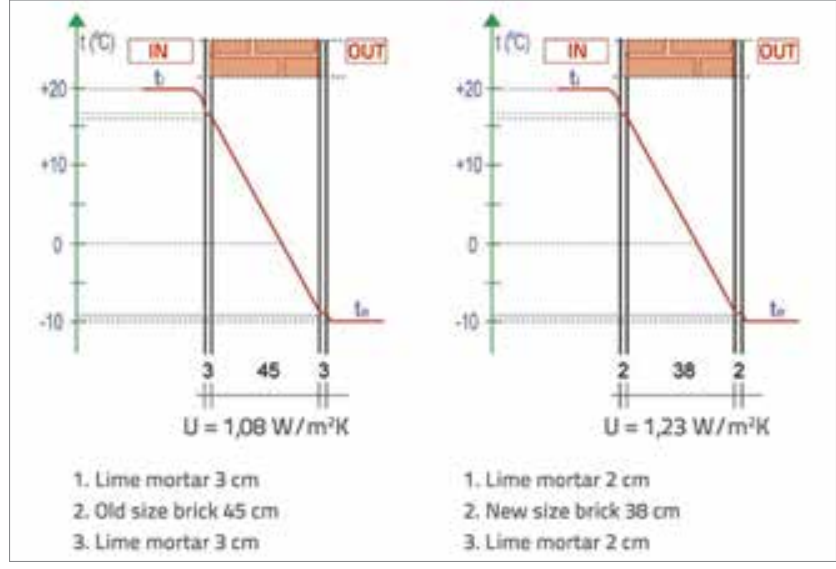

Figure 3. Typical external walls 1901 to 1945

\subsubsection{Construction period $1946-1975$}

Further technical and technological progress in construction of buildings, and widespread use of reinforced concrete resulted in the utilization of materials, in a static sense, to the utmost limits. Consequences were construction of very thin structures of bearing walls that are very bad in thermal terms. Such construction of peripheral structures, often without any insulation, was the result of very cheap energy needed to heat buildings and the lack of adequate regulations in the field of building physics.

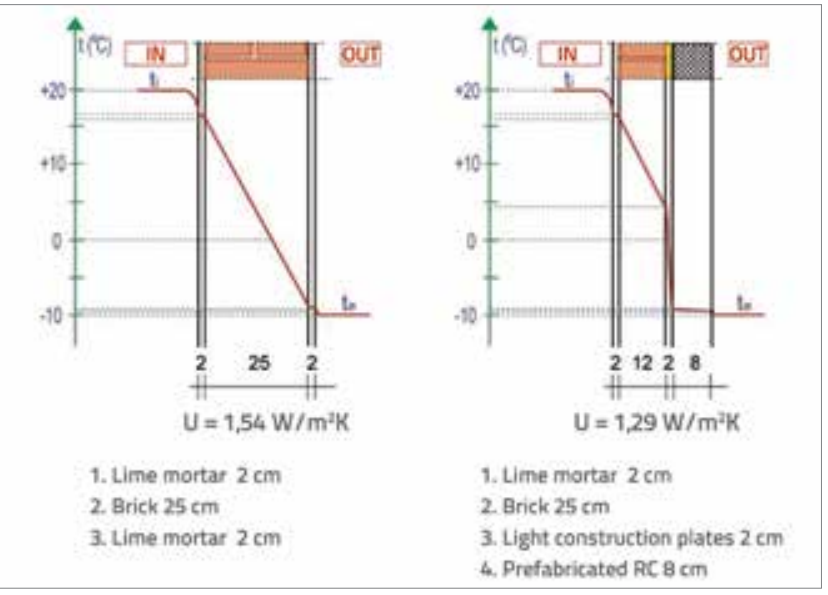

Figure 4. Typical external walls 1946 to 1975

This construction method resulted in a number of buildings with very poor - insulation properties. In Figure 4 shows the temperature curves, and very high thermal transmittance coefficient " $U$ " of most frequently built external walls. Another example is often built prefabricated parapet wall in multiapartment residential buildings. Other peripheral structures built during this period were also very poor in thermal terms. During the 60s and by the mid 70s of the past century, a large number of residential buildings with poor thermal-insulation properties was built. Just in this period building production was at very high levels. Buildings older than 50 years have a significant share in energy consumption for heating residential buildings. According to estimates, annual energy consumption of these buildings amounts to $230-250 \mathrm{kWh} / \mathrm{m}^{2}$ and they account for about $20 \%$ of the total housing stock [4]. The big issue is that these buildings will be in use for many years. Unless they are rebuilt, i.e. new layers of thermal insulation is added, each of these buildings will unnecessarily spend (waste) very large amounts of energy for heating in winter and cooling in summer period.

The external walls of buildings from that period have in average 4-5 times poorer thermal insulation compared to the one that is made today. A small number of these buildings was reconstructed until today with a substantial improvement in thermal insulation. It certainly suggests that very large energy savings, which can significantly contribute to the rational (efficient) use of available energy, can be achieved by the systematic renewal of the building envelope in thermal terms.

\subsubsection{Construction period $1976-1985$}

The energy price rise caused by the first and second oil shock in the seventies and the emergence of the first systematic regulations with mandatory application in the field of thermal protection of buildings lead to better construction of buildings during this period [2]. Although these regulations were enacted in 1970, even by 1975 buildings were constructed almost with no insulation because of applied procedures of permit issuance. Better construction of external walls in this period inevitably involved placing of separate layers of thermal insulation of high quality materials. These are mostly expanded polystyrene, stone or glass wool with coefficient of thermal conductivity $\lambda$ of approx. $0.041 \mathrm{~W} / \mathrm{mK}$.

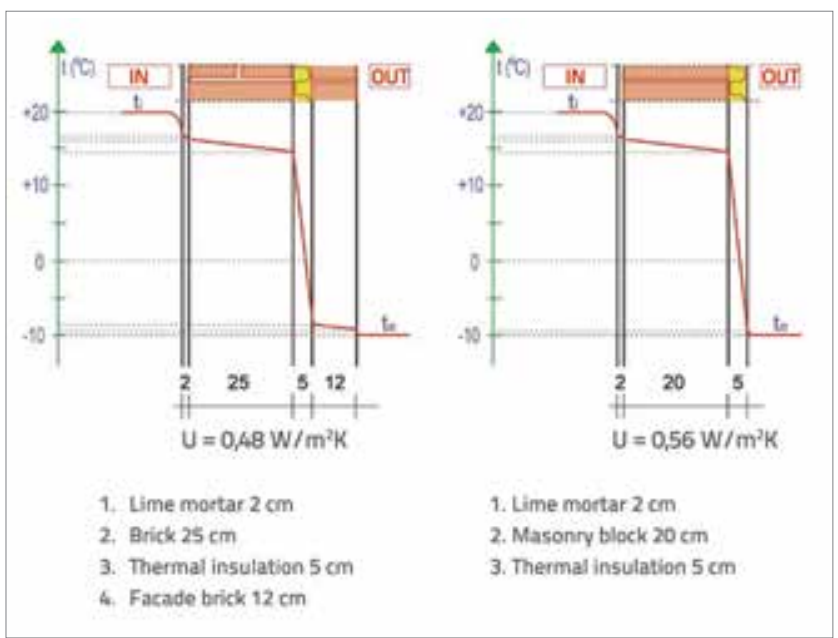

Figure 5. Typical external walls 1976 to 1985

\subsubsection{Construction period $1986-2000$}

This construction period is characterized by a further abrupt increase in energy prices and the systematic adoption of 
more and more demanding regulations in the field of thermal protection of buildings. The awareness of investors about the unquestionable need to perform thermal protection of peripheral building structures has been rising during this period. This often led to construction of buildings with a lot of, in thermal terms, better peripheral elements than those prescribed by the legal provisions. More and more expensive fuels and fuel shortages in mid-80s of the past century were the reason behind it.

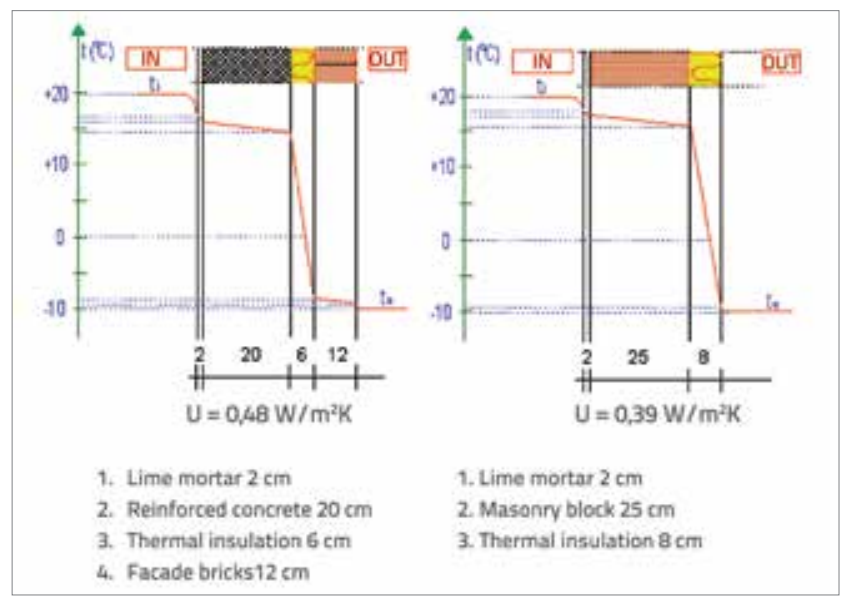

Figure 6. Typical external walls 1986 to 2000

\subsubsection{Construction period since 2001 to date}

Over the last ten years the quality level of construction of peripheral elements in thermal terms has significantly raised in building construction in the region. This was significantly influenced by new Technical regulations on thermal energy saving and thermal protection of buildings from 2005 [6] which, apart from a comprehensive prescribed thermal protection of buildings, for the first time introduced the calculation of heat gains from solar radiation and internal heat sources that reduce the needs of a building for thermal energy in an average heating season.

European regulations and standards have motivated a number of investors and building designers to design and construct buildings with much better thermal insulation properties than those prescribed by the Technical Regulation from 2005. This primarily relates to construction of low-energy and passive houses that represent the initial steps in the design of highly energy efficient buildings. Peripheral structures of such buildings have separate insulation layers with thickness of 15 to $30 \mathrm{~cm}$ which exceeds several-fold the prescribed minimum requirements of thermal protection. Figure 7 shows the temperature curves for the most frequently built compositions of external walls in this construction period.

Some buildings from this period are the first examples of a new comprehensive multidisciplinary approach to the design in construction of buildings with very low or no energy consumption needed for heating. In these buildings, for the first time, the building envelope is systematically designed in terms of airtightness, which is an essential prerequisite for controlled ventilation.

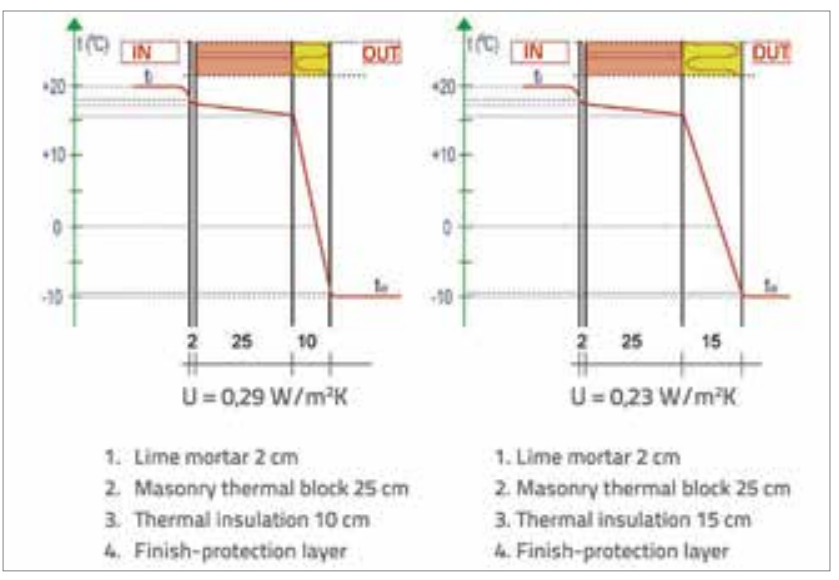

Figure 7. Typical external walls since 2001 to date

During this construction period, more and more buildings that used different types of renewable energy sources were built, which represents the beginning of a new era in design and construction of highly energy efficient residential buildings. Such approach to construction of buildings gives a significant contribution to the essential requirements for sustainable development, energy conservation and protection of the human environment.

Analysis of thermal quality of performed external building walls in the last hundred years in the previous examples shows very large fluctuations. Graphical representation of the change in the average quality of thermal insulation of external walls through different periods of construction is shown in Figure 8.

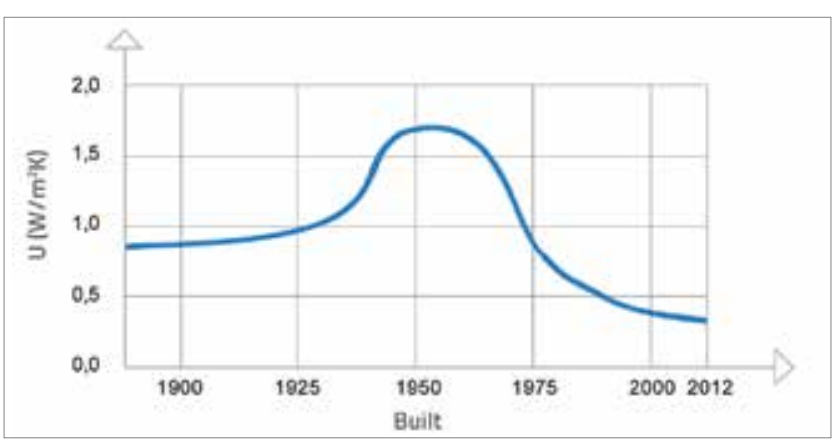

Figure 8. Change in thermal quality of external walls

\subsection{Thermal quality of transparent envelopes of residential buildings}

The term transparent peripheral building structures, except windows, refers to all elements of the building envelope that allow light penetration (fixed glazing, skylights, balcony doors, etc.). The thermal quality of windows is mostly affected by the following elements:

a) number of glass surfaces and thickness of air layers between transparent materials (transmission heat loss)

b) material used to build the frame and method of the frame elements connection (heat transmission loss)

c) adhesion of mobile elements to fixed elements or good tightness (ventilation heat losses). 
Thermal quality of windows installed in residential buildings in the last hundred years varied significantly. This especially refers to the last few decades, during which the thermal transmittance coefficient " $U$ " for windows fell from an average of 3.0 to $0.7 \mathrm{~W} / \mathrm{m}^{2} \mathrm{~K}$ which is the standard for passive and low- energy houses. Materials for window frames, glass types and their processing, as well as closed air spaces between the panes filled later with various types of gases had a significant role in technical improvement of window construction. Overview of the different types of windows installed in residential the building illustrates the huge difference in the thermal quality and airtightness. Technical regulation on energy savings and thermal protection of buildings [7] provides airtightness classes of windows, doors and skylights under HRN EN 12207.

\subsubsection{Single-glazed window}

Installing single-glazed windows with in residential buildings is very rare and it was done only in very small and auxiliary buildings. This type of window can also be found in older buildings in auxiliary room (closets, pantries, toilets, etc.). Thermal quality of single windows is very weak, and thermal transmittance coefficient " $U$ " varies from 5.0 to 6.0 $\mathrm{W} / \mathrm{m}^{2} \mathrm{~K}$ depending on the material used for the frame and glass type (Figure 9).

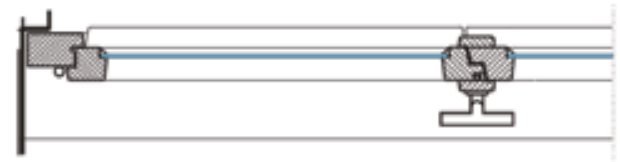

Figure 9. Horizontal cross-section of a single-glazed doublesash window

\subsubsection{Double window}

Double window with wooden frame was the standard method for constructing windows in residential buildings until the mid of 20th century. Double window consists of two single windows with single glass, connected in the whole by a window frame. Wings open inwards, although in the first designs the inside wing opened inwards, and outside outwards, which is seen in the older buildings. Thermal quality of double windows is weak and usually is $\mathrm{U}=2.4 \mathrm{~W} / \mathrm{m}^{2} \mathrm{~K}$. Window frames were made almost entirely of wood.

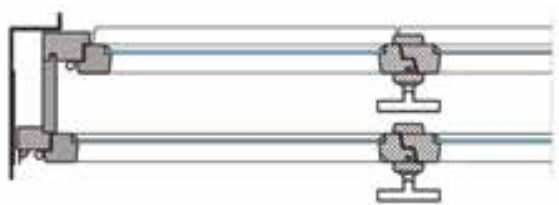

Figure 10. Horizontal cross-section of double double-sash window

\subsubsection{Composite window (sash on sash)}

Composite window is a transitional form between double and single insulated (IZO) window. It was installed in different variations throughout the 60 s and 70 s of the past century in a very large number of residential buildings. Thermal quality of single window is weak, and thermal transmittance coefficient "U" varies from 2.7 to $3.3 \mathrm{~W} / \mathrm{m}^{2} \mathrm{~K}$ [5] depending on the frame material and glass types.

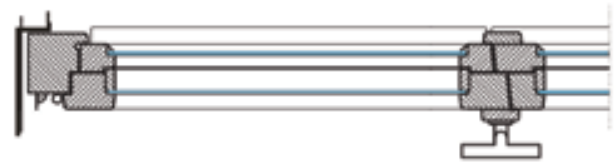

Figure 11. Horizontal cross-section of composite window

\subsubsection{Single window with insulating (double) glass}

Single window with insulating (double) glass is a newer design created in response to increasing demands in terms of thermal protection of buildings that were systematically enacted on two occasions i.e. in 1980 and 1987.

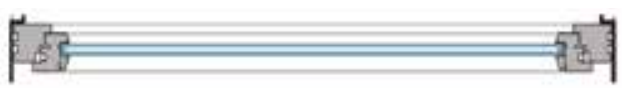

Figure 12. Horizontal cross-section of single window with insulation glazing

Large number of these windows was installed in residential buildings during the $80 \mathrm{~s}$ and $90 \mathrm{~s}$ of the past century. Thermal quality varied depending on the frame quality and the quality of materials used for glazing. Most frequently installed joined-wing window had a wooden frame and double insulating glass with enclosed air layer $(4+12+4)$. The thermal transmittance coefficient " $U$ " for an installed window was 2.9 to $3.4 \mathrm{~W} / \mathrm{m}^{2} \mathrm{~K}$ which depended on the frame material [5].

Intensive development of window production technology resulted in significant rising of the overall quality, particularly relating to sealing, i.e. large reduction of ventilation heat losses through the window hinges (Figure 13).

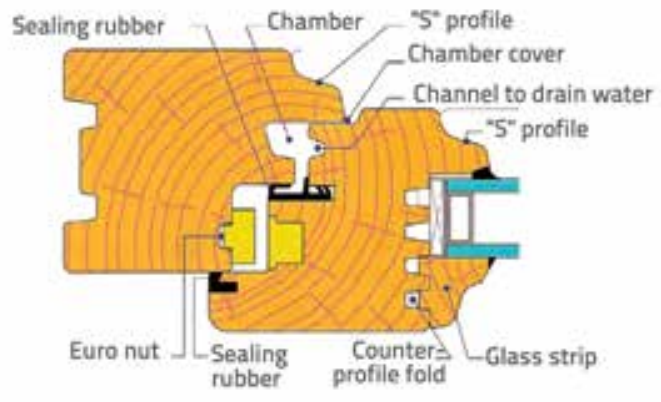

Figure 13. Detail of wooden window with insulating glasses 
Today's designs of wooden windows with double insulating glazing are significantly improved in terms of thermal quality. New regulations require a separate check of thermal quality of window glazing and frames, as well as spacers, i.e. strips for insulating glass. Recently, in order to prevent excessive heat loss from buildings there have been significant improvements in window design. Owing to application of new materials such as low-emission (low-e) coatings and inert gas fillings, thermal transmittance coefficient Ug for glass surfaces was reduced to acceptable 1.2 to $1.4 \mathrm{~W} / \mathrm{m}^{2} \mathrm{~K}$ [1]. Frames of window sashes and jambs have an important role in achieving good thermal insulation properties. Figure $14 \mathrm{~A}$ shows a sectional view of a modern wooden window with double insulated glazing with a value of thermal transmittance coefficient $U=1.2 \mathrm{~W} / \mathrm{m}^{2} \mathrm{~K}$.

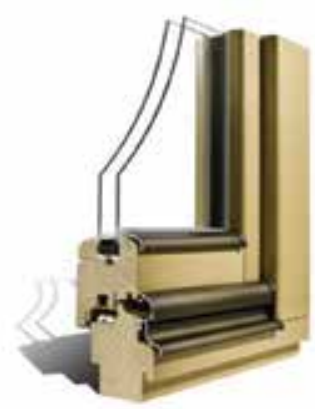

Figure 14. Detail of wooden window with insulating glazing

\subsubsection{Windows with triple glazing}

Technological advances in window production were additionally encouraged by requirements for designing low-energy and passive houses. It was found that the conventional two-layer glazing cannot provide stringent requirements on thermal insulation of such buildings. Special windows with triple thermal insulation glazing (Figure 15), with maximum $\mathrm{Ug} 0.7 \mathrm{~W} / \mathrm{m}^{2} \mathrm{~K}$ were produced for construction of passive houses. Thermal transmittance $U g$ is measured in the centre of a very large surface area so that the measured value is not affected by the effects of the glass edges, window frame and method of installation.
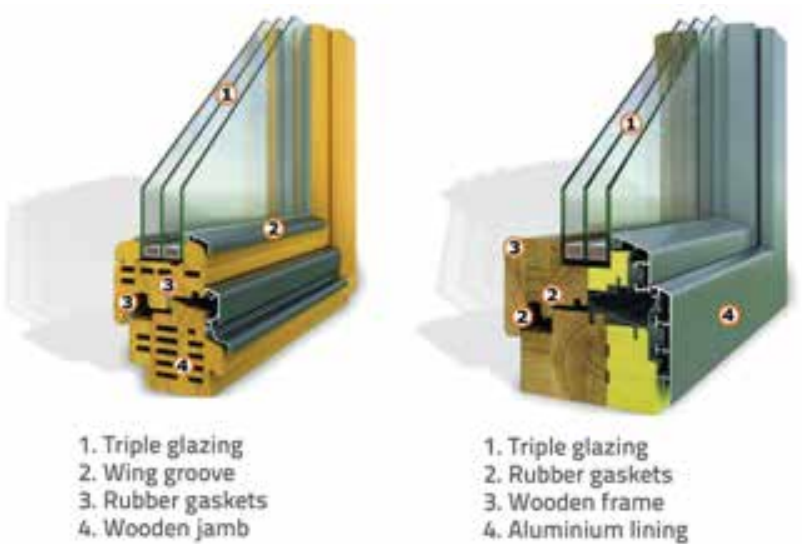

Figure 15. Detail of a wooden window with triple glazing: a) without frame thermal protection; b) with frame thermal protection
Air cavity inside the window jambs and wooden frame of window pane can further contribute to the reduced heat conduction.

Improvement of thermal insulation properties of glazing was reached by filling the space between two glasses with noble gas, usually argon or krypton. Improvements to the window frame (window jamb and pane frame) are made by the installation of additional layers of thermal insulation that protects the external side of frames made of wood, aluminium or PVC (Figure 16). For this purpose cellulose or wood fibres, polyurethane foam and similar materials are used.

\subsubsection{Windows with quadruple glazing}

Further development of production resulted in quadrupleglazed windows. One such example is shown in Figure 16. Slightly extended external air layer in this window allows installation of aluminium venetian blinds as protection from the sun which is placed between the glass panes.

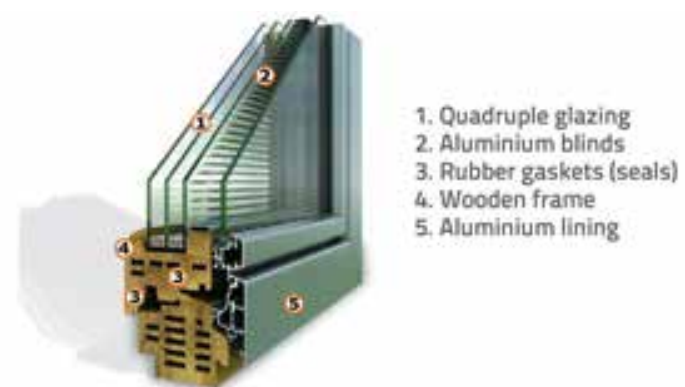

Figure 16. Wooden window with quadruple glazing

\subsubsection{Windows with PVC frames}

In last twenty years windows with PVC frames were also installed in residential buildings. At first these were only smaller windows with poor thermal insulation properties. Use of better quality materials and combining PVC profiles with steel reinforcements, and use of profiles with interrupted thermal bridges have led to the widespread use of PVC windows today. Thermal characteristics have changed and have been constantly improving. Specifications of one reference domestic manufacturer of PVC windows show that a double glazing window has total $\mathrm{UW}=1.0 \mathrm{~W} / \mathrm{m}^{2} \mathrm{~K}$, and a triple glazing window $U \mathrm{w}=0.83 \mathrm{~W} / \mathrm{m}^{2} \mathrm{~K}$ (Figure 17).
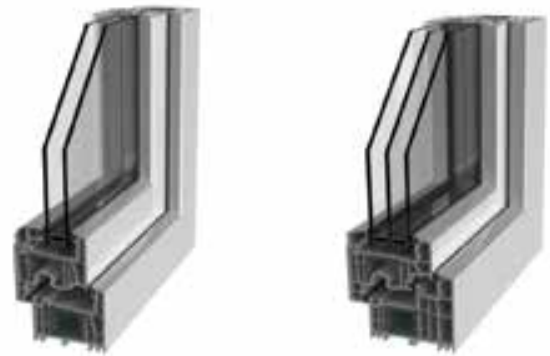

Figure 17. Details of PVC window 
All above examples of windows with their corresponding values of the thermal transmittance coefficients of " $U$ " are theoretical. Actual situation is worse because the wood frame dries up with time, window wings do not seal well, possible glass breaks or detached from the frame and the thermal quality is rather reduced. It is estimated that long-term use of windows in time can cause minor damage which increase the heat transmittance coefficient " $U$ " up to $20 \%$.

Analysis of thermal quality of windows installed in residential buildings in the last hundred years in above examples shows a continuous trend of improvement, which refers especially to the last two decades. Approximate graphical representation of changes in the average thermal quality of windows through different periods of construction is shown in Figure 18.

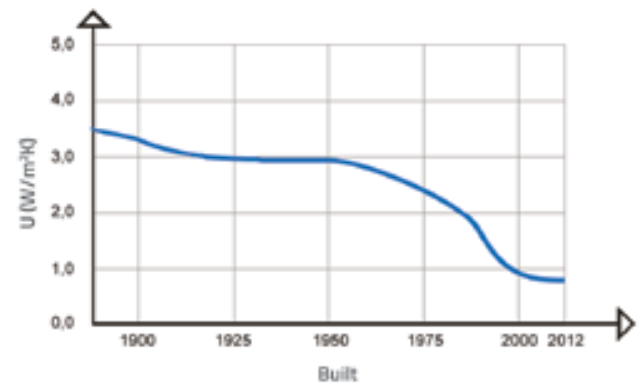

Figure 18. Change in the window thermal quality

\subsection{Impact of position and orientation of residential unit in the building}

Measurement of airtightness in residential buildings can be implemented for the entire building or individually for each residential unit. The apartment position compared to the building envelope is rather important. An apartment in the building can be located so that it has only one external wall, but there can also be as much as 4 or 5 peripheral structures that separate the external or unheated space from the interior heated space (Figure 19).

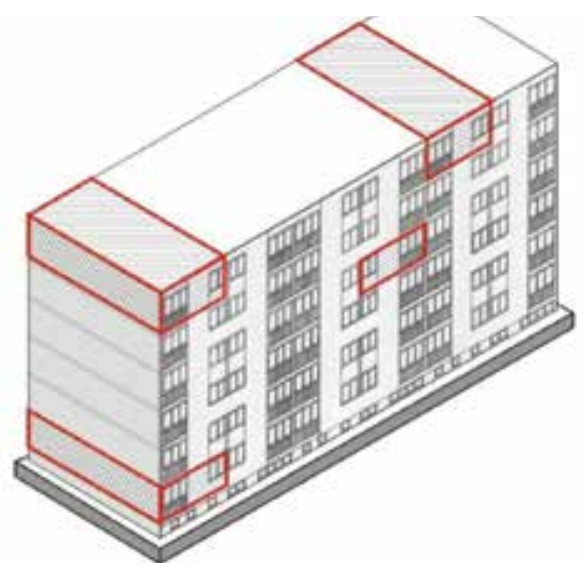

Figure 19. Spatial position of an apartment in the building
For the purpose of measuring airtightness it is best to calculate the percentage of the peripheral structures separating heated from unheated spaces in total envelope area. Theoretically, in a detached house with unheated basement, this percentage may be $100 \%$.

Orientation toward the cardinal points is also important for airtightness of each housing unit. Exposure certain peripheral elements of an apartment to wind of can significantly affect the measured airtightness values. In measuring it is necessary to take into account the temperature difference and wind speed and correct results accordingly, if necessary, [12]. The emergence of wind may not be caused only by local climatic conditions. The height of individual floor, as well as the position of neighbouring buildings in the immediate vicinity and the terrain configuration can also be the cause of wind, i.e. increased airflow.

\section{Airtightness measurements in buildings}

The term airtightness indicates the intensity of uncontrolled air flow through the envelope in or out of the building due to the pressure difference in inside and outside air. Uncontrolled air flow can occur through expansion joints, joints of different materials, expansions and at other permeable spots in the building envelope. Reliable measurement of airtightness in buildings is usually performed using two different methods: pressure difference method ("blower door" test) and "tracer gas" test.

\subsection{Pressure difference test ("Blower door" test)}

The pressure difference method ("blower door" test) is the most applied method for measuring airtightness, and the method is described in details in Standard HRN EN 13829:2002, which is stipulated by Technical regulations about thermal energy savings and thermal protection in buildings (110/08). Studies show that the airtightness demonstrates the characteristics of seasonal variability. Buildings show the highest air leakage in winter and early spring, and the lowest is in late summer [8]. The influence of variable external factors on air leakage from / to objects in the natural environment leads to a number of significant problems. The measured results are difficult to be reproduced and cannot be compared with the results of measurements that were not made in the same weather conditions. For this reason, measurement under positive or negative pressure difference were introduced, because the pressure difference reduces the impact of external factors on the measurement results.

The method's name ("Blower Door" test) stems from the fact that the measurement technology based on the use of high power fan (blower) that is installed to the frame of the entrance door (door) suctions (blows out) air from the inside of the building by creating negative pressure (Figure 20), but 
the application by creating excess pressure in the measuring area is also possible.

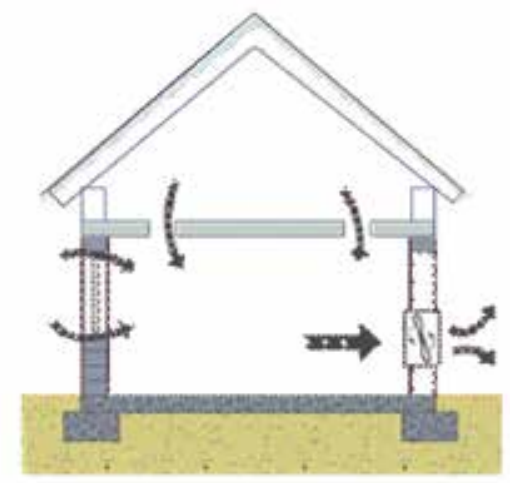

Figure 20. "Blower door" method [9]

The first measurements of airtightness by applying the pressure differences were made in Sweden [10], but the fan was mounted on the window frame, not on the door frame. Equipment for the method "Blower Door", which is generally used today, was improved by the scientific team at Princeton University [10].

Airflow measurement is done in several points of pressure differences in the range of $\mathrm{min} .10 \mathrm{~Pa}$ to $100 \mathrm{~Pa}$. For individual apartments and smaller buildings measurements should be made at pressure differences up to at least 50 $\mathrm{Pa}$, but the recommendation is to make $\mathrm{t}$ measurements for larger pressure differences (100 Pa), because ensure better accuracy of measured results. For large buildings, where the prescribed pressure differences (50 Pa) cannot be reached, the minimum acceptable measurement results are those obtained at pressure difference of $25 \mathrm{~Pa}$ [12]. Standardization of measurement method [12] and recommended pressure difference, which is considered as reference, although not mandatory (Switzerland and France use lower pressure difference) was adopted with the aim to make measuring results comparable and repeatable. At low pressure difference measurement results of volumetric air flow showed significant sensitivity to external weather characteristics. Pressure difference of $50 \mathrm{~Pa}$ was chosen because high pressure difference minimizes the influence of external conditions, such as the impact of seasonal variability and wind, on measurement results [10].

Results of field measurements show that the measured air flow at standard pressure difference for buildings with similar quality of outer envelope, but different sizes, will be different [10] In order to prevent possible error in assessing, normalization is introduced i.e. air flow per the envelope unit area is calculated which enables direct comparison of buildings of different sizes.

In accordance with [12] it is recommended to make two sets of measured data of air flow in the same building (residential unit) at underpressure and overpressure, but one set of measured data under negative pressure or overpressure is also acceptable. An example of graphic interpretation of the measured results of air flow is shown in Figure 21.

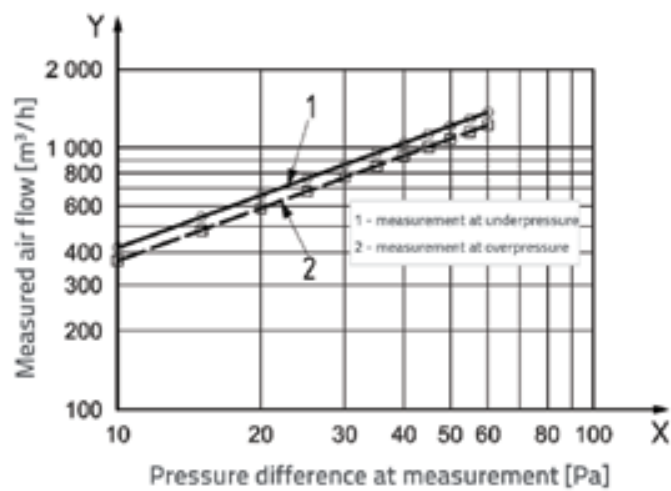

Figure 21. Example of graphic interpretation of measurement results [12]

"Blower door" test measures the airtightness of buildings or parts thereof, and it can be used to compare different buildings or designed and performed airtightness of the envelope structures. "Blower Door" test can be used to diagnose problems of uncontrolled air flow, but the flow is not directly measurable by this method. For determination of maximum permeability it is necessary to use additional test methods (such as smoke, infrared cameras, etc.).

\section{2. "Tracer gas" test}

"Tracer gas" test is used as a diagnostic method of different applicability, and in this case for indirectly determining the uncontrolled air flow direction in the residential units. "Tracer gas" test is carried out in normal exploitation conditions, and the results can be interpreted and compared only with specified values of the influence of external parameters such as wind, insolation, temperature [11]. "Tracer gas" test is based on measuring the gas concentration. Selected gas must meet the following requirements:

- Safety - should not be dangerous for people and property, and shall not affect the activities carried out in the vicinity of the measuring zone, which means that it must be nonflammable, non-toxic and hypoallergenic,

- Inertness (non-reactivity)y - should not enter into chemical or physical reaction to anything in the area of measurement, or outside,

- Insensibility - should not affect those indicators that are the subject of measurement, such as air flow and air density,

- Uniqueness - it should not be a gas which is normally present in the atmosphere, to be able to detect its presence in low concentrations,

- Measurability - concentration must be measurable by existing instruments. 
The successful application of "Tracer gas" test and use of obtained results is used in compliance with the basic requirements. The measuring zone must not be in direct communication with the open space (open windows, doors, etc.). Gas used in the test must be well dispersed and homogeneous, which means that its concentration in the area of measurement should be uniform. The main reason that leads to measurement errors is insufficient mixing level and dispersion of the gas whose concentration in the measuring zone is detected.

Air flow measurement in the observed residential unit or building is usually made using one of these methods:

- a certain gas concentration is achieved and decline of gas concentration as function of time is measured,

- by constant gas inflow increase in gas concentration as a function of time is measured,

- constant gas concentration is maintained, and gas amount as function of time required to maintain the constant concentration is measured

From results of gas concentration measurements the air amount infiltrated to the measurement zone in the observed period is obtained.

\section{Discussion}

It was hypothesized that the airtightness is correlated with the thermal quality of external walls and windows, which are analyzed in this paper. Thermal quality shows considerable variability in the mentioned elements of building envelope in different periods of construction that are typical for building heritage in local conditions. Studies so far have shown that the airtightness (infiltration coefficient) is affected by the structural characteristics of the building, environment, age of the building and climatic conditions [13]. Measurements have shown that massive building structures have lower airtightness than wood and lightweight building structures [14]. According to analyzes made in this paper, the thermal quality of the building envelope components in different periods of construction are described by the thermal transmittance coefficients $\mathrm{U}\left(\mathrm{W} / \mathrm{m}^{2} \mathrm{~K}\right)$ for the external walls of buildings, shown on diagram in Figure 8, and for windows on diagram in Figure 18.

In order to get a realistic insight into the current state of the energy characteristics of the buildings that are used under today's conditions, it is necessary to carry out field measurements of the airtightness of typical residential units. Measurement shall be performed on a representative sample that will best represent the construction features in local community. After completion of airtightness measurement and after analysis of results quality guidelines for the reconstruction of certain categories of buildings to increase energy efficiency can be made.
When planning the experimental part of the study it is necessary to consider several methods for selecting optimal representative sample on which airtightness measurement will be made. Input parameters (factors) that correlate with airtightness should be selected for test performance.

The measured parameters include of thermal transmittance coefficients of opaque and transparent building envelope elements and the position of a housing unit in relation to the outer envelope of the building. For selected input parameters, the results of the analysis that is presented in this paper, are high and low levels of thermal transmittance for the analyzed period of construction are defined according to the results of the analysis presented in this paper, as shown in Table 1. Position the analyzed housing unit in relation to the building envelope is described by the expression PV / PU * $100(\%)$, where PV is the outer envelope surface of the housing unit, and PU is the outer surface area of the envelope of the analyzed housing unit. Based on the selected threshold values (levels) parameters defined in Table 1 the optimal plan of an experimental field study can be selected to get as more as possible reliable information (on which the airtightness model will be based) with as smaller number of conducted field measurements. The possibility of application of neural networks in predicting airtightness should be investigated

Table 1. Input parameters and supposed limit values for planning the experiment

\begin{tabular}{|l|c|}
\hline Input parameters & Limit value \\
\hline $\begin{array}{l}\text { Thermal transmittance coefficient for external } \\
\text { walls } U\left(\mathrm{~W} / \mathrm{m}^{2} \mathrm{~K}\right)\end{array}$ & $0,25-1,8$ \\
\hline $\begin{array}{l}\text { Thermal transmittance coefficient for windows } \\
\mathrm{U}\left(\mathrm{W} / \mathrm{m}^{2} \mathrm{~K}\right)\end{array}$ & $0,7-3,5$ \\
\hline $\begin{array}{l}\text { Position of housing unit in relation } \\
\text { to the building envelope }\end{array}$ & $10-100 \%$ \\
\hline
\end{tabular}

\section{Conclusion}

Controlled air exchange is a very important element in achieving the energy efficiency of low-energy buildings being the target in the current conditions. Airtightness characteristics of housing units in buildings are important to ensure adequate controlled ventilation. The paper presents an analysis and summary of thermal quality for different periods of construction, described by the heat transmittance coefficient $U\left(\mathrm{~W} / \mathrm{m}^{2} \mathrm{~K}\right)$ for selected portions of residential building envelopes building heritage in the local community. Based on the analysis results input parameters were selected under assumption they correlate with airthigthness. Selected parameters and total lower and upper levels are the basis for planning the experiment through mathematical modeling of the selected parameters and optimization of the number of airtightness measurements. 
The analysis of selected parameters (building envelope and location of a residential unit) pointed to the need to establish criteria for selection of a representative sample of housing units for which airtightness measurements should be performed in situ, with minimal consumption of resources available. The established database of measured results will provide a starting point for design of the airtightness prediction model and analysis of building renovation that need to be taken to increase energy efficiency, thermal comfort and convergence with requirements of EU Directive relating to the energy performance of buildings.

\section{REFERENCES}

[1] Zbašnik Senegačnik, M.: Pasivna kuća, SUN ARH, 2009.

[2] Pravilnik o tehničkim mjerama i uvjetima za toplinsku zaštitu zgrada,Službeni list SFRJ 35/70.

[3] JUS U.J5.600 - Toplinska tehnika u gradevinarstvu- Tehnički uvjeti za projektiranje i gradenje zgrada,1980.

[4] Marđetko-Škoro N., Fučić L. , Bertol-Vrček J.: Tehnički propisi o uštedi toplinske energije i toplinskoj zaštiti u zgradama, Gradevinar 57 (2005), 485-493

[5] HRN U.J5.600 Koeficijenti prolaska topline $\mathrm{k}$ za prozore balkonska vrata u zavisnosti od ostakljenja i materijala okvira, Tehnički uvjeti za projektiranje i građenje zgrada iz 1987.

[6] Tehnički propis o uštedi toplinske energije i toplinskoj zaštiti u zgradama (NN 079/2005.)

[7] Tehnički propis o racionalnoj uporabi energije i toplinskoj zaštiti u zgradama (NN 110/2008.)

[8] Kim, A. K.; Shaw, C. Y.: Seasonal variation in air tightness of two detached houses, Authorized, Reprint from Special Technical Publication ASTM STP 904, Measured Air Leakage of Buildings (1986), pp. 17-32, American Society for Testing and Materials, Philadelphia

[9] Ontario Power Authority: A Guide to EnerGuide: What's Involved? Dostupno na (02. 03. 2012.): https://saveonenergy. ca/Consumer/Programs/New-Residential-Construction
[10] Sherman, M.H.: The use of blower-door data, Indoor Air 5 (1995), 215-224

[11] Sherman, M.H.: Tracer-gas Techniques For Measuring Ventilation in a Single Zone, Building and Environment, 25(1990), 4, 365-374

[12] HRN EN 13829 Toplinske značajke zgrada - Odredivanje propusnosti zraka kod zgrada - Metoda razlike tlakova (ISO 9972:1996, preinačena; EN 13829:2000), Hrvatski zavod za norme, veljača 2002.

[13] Sfakianaki, A., Pavlou, K., Santamouris, M., Livada, I., Assimakopoulos, M.N., Mantas, P., Christakopoulos, A.: Air tightness measurements of residential houses in Athens, Greece, Building and Environment 43 (2008) 398-405

[14] Jokisalo, J., Kurnitski, J., Korpi, M., Kalamees, T., Vinha, J.: Building leakage, infiltration, and energy performance analyses for Finnish detached houses, Building and Environment 44 (2009) 377- 387

[15] DIRECTIVE 2010/31/EU of the European Parliament and of the Council, Official Journal of the European Union, 2010, 153/13 - 34, http://www.energy.eu/directives/2010-31-EU. pdf 